\title{
Recovery of Damages from the Head of an Economic Entity: Legislation of the Russian Federation and Law Enforcement Practice
}

\author{
Y.A. Dorofeeva ${ }^{1 *}$ and M.N. Zubkova ${ }^{2}$ \\ *Corresponding author: $\log 1612 @$ yandex.ru \\ ${ }^{1}$ Samara State University of Economics, Samara, Russia \\ ${ }^{2}$ Samara State University of Economics, Samara, Russia
}

\begin{abstract}
A legal entity as a union recognized in law and absent as an independent entity outside the law, exists and carries out its activities through the governing bodies whose composition and competence are always predetermined by the norms of positive law. Undoubtedly, the rights of the governing bodies of a legal entity, as well as the duties of the head of the organization, must be strictly predetermined and have limits defined by law. Failure of this rule would mean the possibility of abuse of the right by the governing bodies of legal entities, their release from the obligation to lead the organization in good faith and reasonably, evasion from the fulfillment of obligations assumed by the legal entity through the sole executive body or another governing body of the organization. In order to prevent harm to the organization and third parties, the governing bodies of the legal entity, the legislator set certain rules for the activities of the governing bodies of the legal entity, as well as the grounds for applying measures of responsibility for violating such rules. The responsibility of the head includes the recovery of damages caused by his fault to a legal entity. The purpose of the study is to analyze the grounds and conditions for recovery of damages caused by the head of the organization in the legislation of the Russian Federation and arbitration practice. The objectives of the study are to determine the grounds for liability of the head of a legal entity in the form of damages, show the genesis of the formation of Russian legislation and the practice of its use by courts on recovering losses of a legal entity from the head of an organization, identify criteria for determining the presence of both good faith and reasonableness in the behavior of managers of legal entities, brought to responsibility in the form of the obligation to pay damages to the organization they lead. In carrying out the study, such methods were used as: general scientific - analysis, synthesis, comparison, generalization, historical method; private-scientific: formal-legal, comparative-legal, allowing to consider the issues of bringing to responsibility in the form of recovery of damages of the head of a legal entity; Formal legal method - for determining the content of abstract categories - reasonableness, good faith, permissible behavior, method of system-structural analysis - to study the possibility of applying damages as a form of responsibility for the guilty behavior of a special entity - the head of a legal entity The result of the study is the establishment of the grounds and conditions for applying to the head (former head) of a legal entity responsibility in the form of recovery of damages caused to the organization managed by it, in the legislation of the Russian Federation and judicial practice. The findings and results of the study can be used for further research and as educational material, in legislative work and in law enforcement practice.
\end{abstract}

Keywords: legal entity, head of legal entity, bankruptcy, guilt, liability, indemnification.

\section{Introduction}

Legal entity is an establishment, created and existing in the world of legal concepts. Deprived of physical content, it is an entirely dependent on the will and behavior of the people managing it. For the purposes of transparency, uniformity and legal certainty, the legislator for each legal form of a legal entity identified possible governing bodies, as well as a specific list of powers (competencies) of the governing bodies of the legal entity, for participants in trafficking. Meanwhile, the abuse of powers of the head of a legal entity in the exercise of the functions of managing an organization does not always conflict with legally established prohibitions of exceeding competence. Sometimes damage to a legal entity is caused by violation of the general legal principle of good faith, the failure of the head of the organization to comply with the requirements of the law to act reasonably and solely in the interests of the organization. In this case, for the head of the organization, as well as for the former head, and in the insolvency procedure (bankruptcy), as well as outside of it, comes the unfavorable consequence of his guilty behavior - the obligation to compensate the victim (the organization he leads) for the damage caused by him. The grounds, conditions and circumstances for the occurrence of such responsibility and exemption from it became possible to establish more thoroughly and in detail, taking into account the changes in Russian legislation, where in 2014 there were special rules on the issue studied in this article, as well as explanations on the application of this legislation published by the highest judicial bodies courts, it is possible to analyze the grounds and conditions for the application of liability in the form of recovery of damages from the head of a legal entity. 


\section{Problem Statement}

In the Russian and foreign literature, the study of the grounds and conditions for recovering damages from the head of a legal entity that caused damages to the organization was carried out in the publications of specialized scientific journals - Gutnikov [1], Lukyanova [2] and at the monographic level, along with other issues of the management bodies of a legal entity - Khokhlov [3], Kuznetsov [4], Osipenko [5], the provisions of international acts of recommendatory nature (Financial Stability Forum (FSF) Principles for Sound Compensation Practices), recommendations of the RF Armed Forces, clarifications a tax provisions in the practice of foreign courts. In this paper, for the first time, the issues of formation and current state of the legislation of the Russian Federation and practice on the issue of liability to the head of a legal entity in the form of damages, in the aspect of the ratio of general and special standards, explanations of their application are investigated.

\section{Research Questions}

As part of this study, the following questions are answered:

What norms of the Russian legislation underlie the responsibility of the head of a legal entity for causing damages in the form of compensation?

How did the legislation of the Russian Federation and the practice of its application by the courts on the issue of recovery of damages of a legal entity from the head of the organization?

What are the criteria of good faith and rationality in the behavior of managers of legal entities?

\section{Purpose of the Study}

The purpose of this study is to analyze the grounds and conditions for recovering damages from to the head (former head) of a legal entity. Also it is to examine the conditions of applying such responsibility in the form of recovery of damages caused to the organization by the person who managed it, to study the grounds established by the legislation of the Russian Federation and the practice of the courts of the Russian Federation.

\section{Research Methods}

In the process of research, the following methods were used: general scientific - analysis, synthesis, comparison, synthesis, historical method; private-scientific: formal-legal, comparative-legal, allowing to consider the issues of bringing to responsibility in the form of recovery of damages of the head of a legal entity; Formal legal method - for determining the content of abstract categories - reasonableness, good faith, permissible behavior, method of systemstructural analysis - to study the possibility of applying damages as a form of responsibility for the guilty behavior of a special entity - the head of a legal entity.

\section{Findings}

The responsibility of the head of a legal entity in the form of the obligation to compensate for damages caused by his fault to the organization headed is established by a special rule - Article 53.1 of the Civil Code of the Russian Federation [6] (hereinafter - the Civil Code of the Russian Federation), which appeared relatively recently in Russian legislation in 2014 [7]. Despite this, in 2015, the Supreme Court of the Russian Federation clarified the practice of applying this rule for courts [8], which indicates both the relevance and ambiguity of the decision on the grounds, conditions and procedure for applying such a measure of responsibility as the recovery of damages to the head of the legal entity. In addition to this special rule, the claim for damages to the head or former head of the legal entity could be made according to the general rule, i.e. on the basis of Art. 15 of the Civil Code, which provides for the obligation to pay damages to the injured person, the fault of which caused losses. The above norm was used by the participants of economic societies, as well as the society represented by the newly elected (appointed) manager, who filed claims for damages caused to the legal entity. The basis of such requirements, except for Art. 15 of the Civil Code, contained special legal norms. Thus, the responsibility of the head of the organization, in respect of which bankruptcy proceedings were instituted, is established by Art. 61.20 of the Federal Law of October 26, 2002 No. 127-FZ "On Insolvency (Bankruptcy)" (hereinafter - the Bankruptcy Law) [9], the responsibility of the sole executive body of a limited liability company is defined in part 2 of Art. 44 of the Federal Law of 08.02.1998 No. 14-FZ "On Limited Liability Companies" (hereinafter - the Law on LLC) [10], of a joint stock company - Part 2 of Art. 71 of the Federal Law of 26.12.1995 No. 208-FZ “On Joint-Stock Companies" (hereinafter - the Law on JSC) [11].

Thus, in the framework of case No. A32-7549 / 2013 [12], under the suit of LLC Yeysk Oil Extraction Plant, LLC AgroPrestige, LLC Agrofirma Stepnaya - the shareholders of OJSC Kanevsksakhar, the court sought from the 
general director of OJSC Kanevsksakhar P.N. Ignatenko losses in the amount of 125,797,621 rubles indicating that the defendant did not comply with the provisions of Part 1 of Art. 71 of the Law on Joint-Stock Companies - to act in the interests of the company in good faith and reasonably, guilty actions involving the sale of the company's products at reduced prices, caused damage to the company. Based on the content of Art. 15 of the Civil Code, the court determined the damage as a value expression of negative property consequences of violation of subjective civil law as a result of the unlawful behavior of another person, recognizing that the calculation of damages for claimants made by determining the difference between the total value of goods at average market prices and the total value of goods under transactions made by P.N. Ignatenko as a CEO on behalf of a joint stock company. Such an application in the case on recovery of damages from the head of a legal entity of a special norm (Art. 71 of the Law on JSC) and the general norm, which discloses the concept of damages and in accordance with which the amount of damages is calculated (Art. 15 of the Civil Code of the Russian Federation), was recognized as correct and by higher authorities in the case.

Even before the adoption of amendments to the Civil Code of the Russian Federation in 2014, the decision of the Plenum of the Supreme Arbitration Court of the Russian Federation No. 62 dated July 30, 2013 [13] provided clarification to the courts on the qualification of abstract categories on which the interpretation of the behavior of the head of the organization is based on determining whether or not guilt was in his actions. As established by paragraph 1 of Art. 44 of the Law on LLC [6], Part 1 of Art. 71 of the Law on JSC [11], the head must act in the interests of the organization he heads in good faith and reasonably. Such an abstract category as rationality is to be determined by the court independently, taking into account the actual circumstances of the case and the evidence submitted by the parties. Using the courts in determining whether the head of the company complies with the requirements of good faith and reasonableness, the Supreme Court of the Russian Federation explained in which cases the head's behavior (actions, inaction) did not meet the requirements of reasonableness - the decision without taking into account the information that is important to him in this situation, not taking preventive actions, aimed at obtaining necessary and sufficient information, which are usual for business practice under similar circumstances, internal procedures adopted in this legal entity, etc. Unscrupulousness is presumed if actions (inaction) that caused damages were committed by the head when there is a conflict between his personal interests and the interests of the legal entity. Note that clauses 4.5 of the resolution of the Plenum of the Supreme Court of Arbitration of the Russian Federation No. 62 of July 30, 2013, extend the responsibility to compensate for the losses caused to cases when a legal entity is involved in tax, administrative and other public liability arising from the unscrupulous and (or) unreasonable behavior of the director, inadequate organization of the legal entity management system, unfair (unreasonable) implementation of duties on selection and control over actions (inaction) of representatives, counterparties on civil rights contracts, employees of a legal entity. In the legal literature there is an example of an incorrect application of the above explanations of the highest judicial authority: contrary to paragraph 5 of the resolution of the Plenum of the Supreme Arbitration Court of the Russian Federation No. 62 dated July 30, 2013, the court brought the head of the company responsible for evasion of convening the board of directors when considering the obligation to local acts of the company was assigned to the chairman of the board of directors [5]. The fact of the adoption of the resolution of the Plenum of the Supreme Arbitration Court of the Russian Federation of July 30, 2013 No. 62 and its content are evaluated positively in the scientific literature. So, A.A. Kuznetsov points out that the resolution complies with the rule established in foreign legal orders: the sole executive body must resist the execution of illegal instructions of the corporate majority, and only execute instructions if they do not contradict his duty to act in good faith and reasonably, as he is by virtue of the law the head of the legal entity is called upon protect the interests of minority participants (shareholders) and third parties [4]. The relevance and significance of explanations for the application of the provisions on bringing to responsibility the managers of a legal entity who have caused the damage to the guilty organization they lead, note O.V. Gutnikov [1], I.N. Lukyanova [2]. Considering that in the Russian legislation the rule on the responsibility of managers of any legal entity who caused losses to the guilty unlawful conduct contrary to the principles of good faith and reasonableness appeared only in 2014 (Article 53.1 of the RF Civil Code), issued by the Supreme Court of the Russian Federation in 2013 clarified to a large extent the existing the gap in the courts' interpretation of the legality of actions (inaction) of managers of legal entities who are held accountable, by which we mean "a certain state (attitude ) violated legal relations, resulting from an offense and characterized by one kind or another of disadvantages - diminution of benefits, distortion of the established order of affairs, etc. "(V.A. Khokhov [3]). Compensation of damages is a measure of liability of a compensatory nature, aimed at restoring the legal and property status of the injured person (Resolution of the Presidium of the Supreme Arbitration Court of the Russian Federation of 21.05.2013 No. 16674/12 [14]). Compensation of damages is a measure of civil liability, the use of which is possible only if the legal composition, the presence of such conditions as: the commission of illegal actions or omissions is proved; the occurrence of damages; a causal relationship between the wrongful conduct and the resulting losses; confirmation of the amount of damages. In this case, by virtue of Part 5 of Art. 53.1 of the Civil Code of the Russian Federation, the possibility of limiting (eliminating) the responsibility of the head of a legal entity for committing unfair actions, including by including the relevant condition in the employment contract, is invalid (void).

\section{Conclusion}

At the beginning of this article, the authors posed three questions, the answers to which can be given from the results of the study. The basis for the application of such a measure of property liability of the head of a legal entity to the 
company is the general rule (Article 53.1 of the Civil Code) and a number of special rules that provide for the responsibility for heads of organizations created in a certain organizational and legal form (Article 44 of the Law on PA, Article 71 of the Law on JSC), as well as in case of insolvency (bankruptcy) of the organization (Article 61.20 of the Law on Bankruptcy). The general rule established in the legislation of the Russian Federation on the application of responsibility to the head of the organization in the form of recovery of damages caused by the organization headed by him began to act after the adoption of special rules governing the recovery of damages from the sole executive body of JSC, LLC, as well as the adoption of legal provisions governing bringing to justice the heads of organizations in respect of which a bankruptcy case was initiated. Moreover, by the time Article 53.1 of the Civil Code of the Russian Federation entered into force, the practice of applying the rules of special legislation by the courts to apply to the heads of bankrupt organizations of the limited liability company in the form of compensation for losses had been established. Thus, the Armed Forces of the Russian Federation have already qualified the abstract categories that underlie the qualification of the guilty behavior of the head of a legal entity - unreasonableness and bad faith, and also named a number of cases when unreasonableness (bad faith) is assumed. All of the above prepared the participants of civil turnover for a uniform interpretation of the norm on property responsibility of the head of a legal entity established in 2014 of any legal form and form of ownership, made it possible to interpret the content of the provision of Art. 53.1 of the Civil Code of the Russian Federation since its introduction, taking into account the established practice on this issue. Criteria for determining the presence of both good faith and reasonableness in the behavior of managers of legal entities are not legally defined, but some of their signs are established by the Supreme Court of the Russian Federation, which makes it possible to directly identify a sign of bad faith in the behavior of the head of a legal entity (for example, when making transactions organizations have an interest), or qualify the actions of these persons from the standpoint of the normal business activities of the organization he heads and actions (inaction) of the manager, as a result of which losses have been caused to the legal entity. The last rule applied in the Russian Federation in accordance with paragraph 5 of the Resolution of the Plenum of the Supreme Arbitration Court of the Russian Federation No. 62 of July 30, 2013 , has also been formed in the practice of foreign courts. So, in the Selheimer v. Manganese Corporation of America, the court brought to responsibility managers who invested the corporation in the purchase of the plant, although they knew that the plant could not operate profitably due to the lack of access to the railway and warehouse facilities [15]. Since "any compensation system should work together with other management tools in the pursuit of prudent risk taking" [16], one should not underestimate the importance of state coordination and consistency in the behavior of business entities in order to prevent the occurrence of damages that will become necessary without delaying the occurrence of a delict.

\section{References}

1. O.V. Gutnikov, Bringing a single member of a commercial corporation to liability for damages caused to a legal entity as a result of the unlawful dismissal of the general director. In V.F. Yakovlev (Ed.), Comment on the practice of resolving economic disputes (judicial arbitration practice), 24, (pp. 68-85). Moscow: SISP, CONTRACT (2018). [in Rus.].

2. I.N. Lukyanova, Consideration of disputes on recovery of losses from management bodies of business companies. Laws of Russia: Experience, Analysis, Practice, 9, 28-35 (2017). [in Rus.].

3. V.A. Khokhlov, General provisions on obligations: Training manual. Moscow: Statute (2015). [in Rus.].

4. A.A. Kuznetsov, The limits of autonomy of will in corporate law. Moscow: Statute. (2017). [in Rus.].

5. O. Osipenko, Actual problems of systemic application of corporate governance and stock law instruments. Moscow: Statute (2018). [in Rus.].

6. Civil Code of the Russian Federation (part 1). Retrieved from: http://www.consultant.ru/document/cons_doc_LAW_5142/. Accessed: 26.12.2018 (1994). [in Rus.].

7. Federal'nyj zakon "O vnesenii ismenenii v glavu 4 chasti 1 Gragdanskogo kodeksa Rossiiskoi Federatzii I o prisnanii utrativshimi silu otdel ’nnyih polodgenii zakonodatel 'nih aktov Rossiiskoi Federatzii” ot 05.05.2014 № 99FZ. Retrieved from: http://base.garant.ru/70648990/. Accessed: 30.12 .2018 (2014). [in Rus.].

8. Postanovlenie Plenuma VAS RF ot 02.06.2015 N 21 "O neckotorih voprosah voznikshih u sudov pri primenenii zakonodatel'stva, reguliruyushchego trud rukovoditelya organizacii i chlenov kollegial'nogo ispolnitel'nogo organa organizacii". Retrieved from: http://base.garant.ru/71061490/. Accessed: 26.12.2018 (2015). [in Rus.].

9. Federal'nyjzakon "O nesostoiatel'nosti (bankrotstve)" ot 26.10.2002 № 127-FZ. Retrieved from: http://www.consultant.ru/document/cons_doc_LAW_39331/. Accessed: 30.12 .2018 (2002). [in Rus.].

10. Federal'nyj zakon "Ob obchestvah s ogranichennoi otvetstvennost ‘u” ot 08.02.1998 №14-FZ. Retrieved from: http://www.consultant.ru/document/cons_doc_LAW_17819/. Accessed: 30.12 .2018 (1998). [in Rus.].

11. Federal'nyj zakon "Ob actzionernich obchestvah" ot 26.12.1995 N 208-FZ. Retrieved from: http://www.consultant.ru/document/cons_doc_LAW_8743. Accessed: 30.12 .2018 (1995). [in Rus.].

12. E-justice (2014). Electronnoe delo v elektronnoy kartoreke arbitrazhnih del Arbitr № A32-7549/2013. Retrieved from: http://kad.arbitr.ru/Card/a6a9deb2-e5ea-49fc-aeca-340ae311ab4d Accessed: 30.12 .2018 (2013). [in Rus.].

13. Postanovlenie Plenuma VAS RF ot 30.07.2013 N62 "O neckotorih voprosah vozmetseniya ubitkov litsami, vhodyatsimi v sostav organov yuridicheskogo litsa" Retrieved from: http://base.garant.ru/70436634/. Accessed: 30.12.2018 (2013). [in Rus.]. 
14. Postanovlenie Prezidiuma VAS RF ot 21.05.2013 N 16674/12 po delu $N$ A60-53822/2011. Retrieved from: http://kad.arbitr.ru/PdfDocument/f74b8e24-3ba3-4575-b091-c21994045884/f8767f4c-1b26-470e-88488805af0b473a/A60-53822-2011_20130521_Reshenija_i_postanovlenija.pdf/. Accessed: 30.12 .2018 (2013). [in Rus.].

15. Melvin A. Eisenberg, The Duty of Care of Corporate Directors and officers. Berkley: University of California Press (1989).

16. Financial Stability Forum, Principles for Sound Compensation Practices. Retrieved from: http://www.fsb.org/wpcontent/uploads/r_0904b.pdf. Accessed: 30.12.2018 (2009). 